\title{
Covid- 19 Confirmed, Recovered, Death Cases In India: Ratio Analysis
}

\author{
Sheetal Bharat Raut, \\ Asst. Professor, Commerce Department ,College Of Computer Science's ,Wakad, Pune, \\ Maharashtra, India. sheetal.raut0684@gmail.com
}

Abstract: The novel coronavirus (COVID-19) has effected the 213 countries around the world.It has declared a Public Health Emergency of International Concern on 30 January 2020 by WHO and created tremendous chaos around the world, affecting people's lives and causing a large number of deaths. On the date of $21^{\text {st }}$ April 2020 total covid

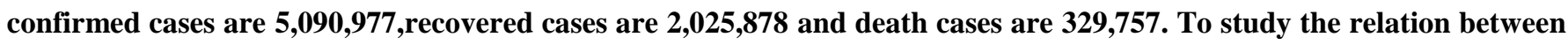
the confirmed, recovered and death cases in India this study has been undertaken . For the same Ratio analysis technique is used. Here will trying to find that the number of recovered cases will have effect the number of death cases.

Keywords: Ratio analysis , confirmed cases, Recovered cases, Death cases,covid 19

\section{METHODS}

Ratio Analysis method have been used to study the the relation between the ratio of recovered cases to confirmed cases and the ratio of death cases to confirmed cases of corona in India.

\section{Data Collection}

_secondary data of corona pandemic cases in India have been collected from the different website. The period of Feb $15^{\text {th }} 2020$ to May $16^{\text {th }} 2020$ has been taken for the analysis. This data has arranged weekly for the study.

Hypothesis:

In this study will going to test null hypothesis that, The change in the ratio of total recovered cases to total confirmed cases does not have effect on the ratio of total death cases to total confirmed cases of corona in India.

\section{INTRODUCTION}

In December 2019, a novel pneumonia of unknown cause was declared in Wuhan, China. By $7^{\text {th }}$ Jan, 2020, Chinese

Table 1: state wise corona cases in India scientists had discovered new coronavirus (COVID-19) from patients in Wuhan.[7] As $16^{\text {th }}$ march , 2020, COVID19 is affecting 162 countries and territories around the world. Consequently, on $11^{\text {th }}$ march , coronavirus declared pandemic[8]

India is a country having 28 sates and 8 union territories. The total population of India on $16^{\text {th }}$ may 2020 is $1,378,122,490$, the second most populated country in the world.[1] From this population 90,648 people has been infected by the covid 19 till $16^{\text {th }}$ may 2020.[2] The first corona positive patient has been found in India 30 January 2020 in the state of Kerala.[6] The Patient had a travel history from Wuhan, China. Now this virus has spread throughout the country. Most effected states in India are Maharashtra, Gujrat, Delhi, Madya Pradesh, Rajasthan, Tamilnadu, Uttar Pradesh, Andhra Pradesh, Punjab, West Bengal. The following table shows the covid total confirmed cases, recovered cases and death cases of above states of India till date $8^{\text {th }}$ May 2020.

\begin{tabular}{|l|l|l|l|}
\hline StateName & Confirmed cases & Recovered cases & Death cases \\
\hline Maharashtra & 17,974 & 3,301 & 694 \\
\hline Gujrat & 7,012 & 1,709 & 425 \\
\hline Delhi & 5,980 & 1,931 & 66 \\
\hline Madya Pradesh & 3,252 & 1,231 & 193 \\
\hline Rajasthan & 3,427 & 1,596 & 97 \\
\hline Tamilnadu & 5,409 & 1,547 & 37 \\
\hline Uttar Pradesh & 3,071 & 1,250 & 62 \\
\hline Andhra Pradesh & 1,847 & 780 & 38 \\
\hline Punjab & 1,644 & 149 & 28 \\
\hline West Bengal & 1,548 & 364 & 151 \\
\hline
\end{tabular}


Above table shows that the state Maharashtra is most impacted state by corona having 17,974 confirmed corona positive cases.[3]Mumbai is the city which has two third cases of Maharashtra. It is worst effected state of india having more than 17000 cases of corona which accounts one third cases of India.[5]

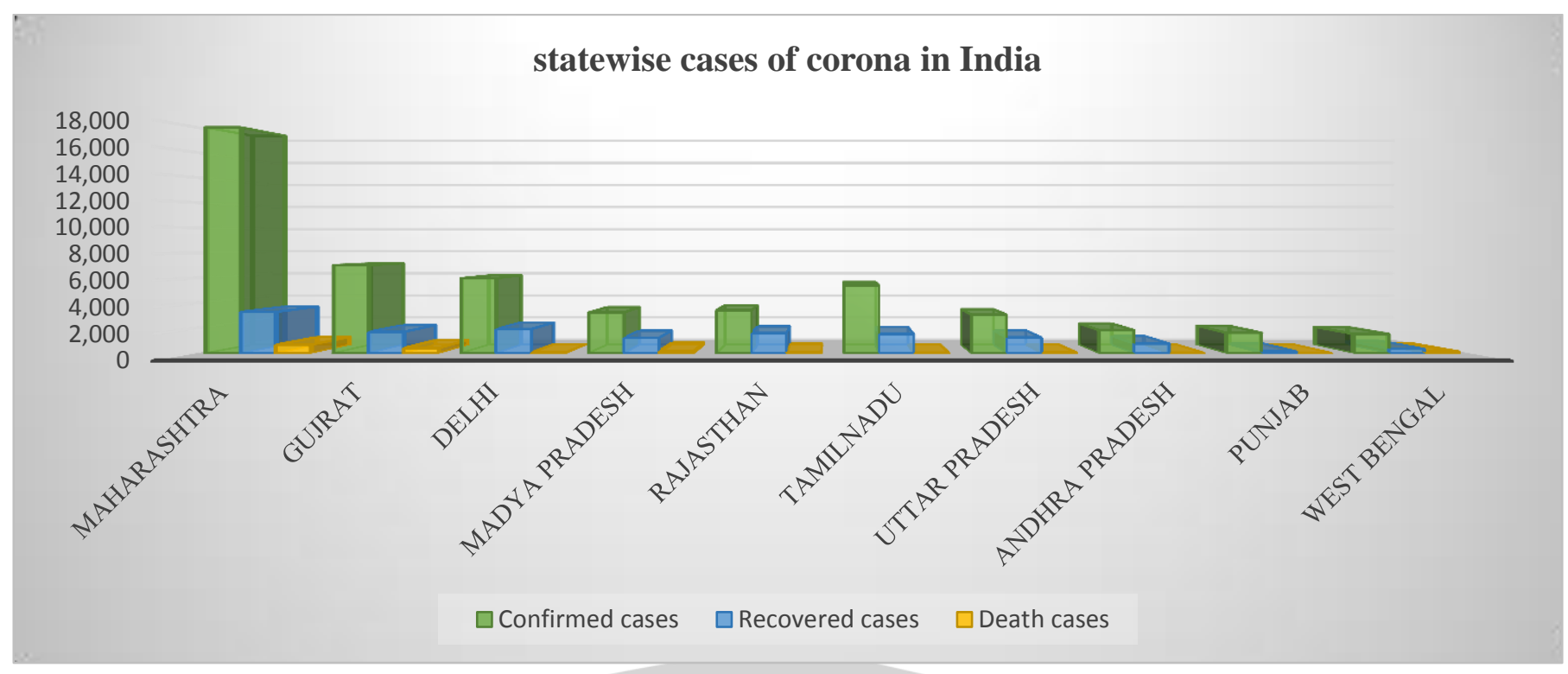

figure 1: state wise corona cases in India

In this study will trying to find the relation between no of recovered cases and death cases in the India due to corona virus. If from the total confirmed cases recovered cases are increasing, whether it decrease the death cases, if recovered cases decrease whether it leads to increase death cases.

Following table shows the weekly data of total corona confirmed, recovered and death numbers in India from $15^{\text {th }}$ feb 20202 to the date $16^{\text {th }}$ May 2020.

Table 2: weekly data of total corona confirmed, recovered and death numbers in India from $15^{\text {th }}$ feb 20202 to the date $16^{\text {th }}$ May 2020.

\begin{tabular}{|c|c|c|c|c|c|c|}
\hline Date & Total confirmed & (increased no) & Recovered cases & (increased no) & Death cases & (increased no) \\
\hline & cases & & & & & \\
\hline Feb $15^{\text {th }}$ & 3 & 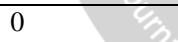 & $0-x+2=1$ & 0 & 0 & 0 \\
\hline Feb $22^{\text {nd }}$ & 3 & +9 & 0 & $0 \quad 8 \%$ & 0 & 0 \\
\hline Feb $29^{\text {th }}$ & 3 & 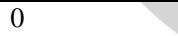 & 0 & 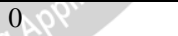 & 0 & 0 \\
\hline Mar $7^{\text {th }}$ & 34 & 31 & 0 ch in Engineer & 0 & 0 & 0 \\
\hline Mar $14^{\text {th }}$ & 100 & 66 & $13-2$ & 13 & 2 & 2 \\
\hline Mar $21^{\text {st }}$ & 332 & 232 & 24 & 11 & 5 & 3 \\
\hline Mar $28^{\text {th }}$ & 987 & 655 & 84 & 60 & 24 & 19 \\
\hline Apr $4^{\text {th }}$ & 3,588 & 2,601 & 229 & 145 & 99 & 75 \\
\hline Apr $11^{\text {th }}$ & 8,446 & 4,858 & 774 & 545 & 288 & 189 \\
\hline Apr $18^{\text {th }}$ & 16,365 & 7,919 & 2,040 & 1,266 & 521 & 233 \\
\hline Apr $25^{\text {th }}$ & 26,283 & 9,918 & 5,500 & 3,460 & 825 & 304 \\
\hline May $2^{\text {nd }}$ & 39,699 & 13,416 & 10,000 & 4,500 & 1,323 & 498 \\
\hline May $9^{\text {th }}$ & 62,808 & 23,109 & 17,900 & 7,900 & 2,101 & 778 \\
\hline May $16^{\text {th }}$ & 90,648 & 27,840 & 30,093 & 12,193 & 2,871 & 770 \\
\hline
\end{tabular}

Above table shows the weekly data of corona patients in India. From the $15^{\text {th }}$ Feb to $16^{\text {th }}$ May there is increase in total confirmed cases i.e. from 3 cases to 90,648 cases in two months period. Same as with increase in confirmed cases recovered cases are also increase from 0 to 30,093. Death cases column shows that on the date of $15^{\text {th }}$ Feb no of death is 0 ,it increase to 2,871 cases till $16^{\text {th }}$ May. As per above table corona confirmed ,recovered as well as death cases are increasing in the two months i.e from $15^{\text {th }}$ Feb to $16^{\text {th May }} 2020$. 
Figure 2: weekly data of total corona confirmed, recovered and death numbers in India from $15^{\text {th }}$ feb 20202 to the date $16^{\text {th }}$ May 2020

\section{Chart total corona confirmed, recovered and death cases in India}

100000

90000

80000

70000

60000

50000

40000

30000

20000

10000

0

Above graph shows the week wise numbers of corona confirmed, recovered and death cases. on the $15^{\text {th }}$ Feb 2020 ,confirmed cases of corona are 3 and recovered and death cases are 0 . Recovered and death cases are 0 till $7^{\text {th }}$ march whereas confirmed cases increase to 34 . The graph implicate growth in the confirmed, recovered and death cases.It has increasing trend. Study has undertaken to find out relation between the ratio of recovered cases to confirmed cases and the ratio of death cases to confirmed cases. Whether it has positive or negative relation between both ratios.

\section{RATIO ANALYSIS}

Definition of Ratio Analysis:

According to Accountant Handbook by Wixon, Kell and Bedford, 'a ratio is an expression of the quantitative relationship between two numbers'.[4] The ratio is calculated by dividing one figure to another figure. Ratio can be expressed in three ways-Time, percentage and proportion. In ratio analysis two figures taken should be connected to each other else ratio will serve no purpose.

Following table shows the Ratio of covid -19 Ratios of weekly Total Recovered Cases /Total confirmed Cases and total Death Cases /Total confirmed Cases from $15^{\text {th }}$ feb 20202 to the date $16^{\text {th }}$ May 2020.

Table 3: Ratios of weekly Total Recovered Cases /Total confirmed Cases and total Death Cases /Total confirmed Cases

\begin{tabular}{|c|c|c|c|c|}
\hline Date & $\begin{array}{c}\text { Total Recovered Cases / Total } \\
\text { confirmed Cases }\end{array}$ & Increase/decrease in \% & $\begin{array}{c}\text { Total Death Cases } \\
\text { /Total confirmed Cases }\end{array}$ & Increase/decrease in \% \\
\hline Feb $15^{\text {th }}$ & $0 \%$ & $0 \%$ & $0 \%$ & $0 \%$ \\
\hline Feb $22^{\text {nd }}$ & $0 \%$ & $0 \%$ & $0 \%$ & $0 \%$ \\
\hline Feb $29^{\text {th }}$ & $0 \%$ & $0 \%$ & $0 \%$ & $0 \%$ \\
\hline Mar $7^{\text {th }}$ & $0 \%$ & $0 \%$ & $0 \%$ & $0 \%$ \\
\hline Mar $14^{\text {th }}$ & $13 \%$ & $13 \%$ & $2 \%$ & $2 \%$ \\
\hline Mar $21^{\mathrm{st}}$ & $7.23 \%$ & $-5.77 \%$ & $1.5 \%$ & $-0.5 \%$ \\
\hline Mar $28^{\text {th }}$ & $8.5 \%$ & $1.27 \%$ & $2.4 \%$ & $0.9 \%$ \\
\hline Apr $4^{\text {th }}$ & $6.3 \%$ & $-2.2 \%$ & $2.7 \%$ & $0.3 \%$ \\
\hline Apr $11^{\text {th }}$ & $9.1 \%$ & $2.8 \%$ & $3.4 \%$ & $0.7 \%$ \\
\hline Apr $18^{\text {th }}$ & $12.46 \%$ & $3.36 \%$ & $3.1 \%$ & $-0.3 \%$ \\
\hline Apr $25^{\text {th }}$ & $20.9 \%$ & $8.44 \%$ & $3.1 \%$ & $00 \%$ \\
\hline May $2^{\text {nd }}$ & $25.1 \%$ & $4.2 \%$ & $3.3 \%$ & $0.2 \%$ \\
\hline May $9^{\text {th }}$ & $28.50 \%$ & $3.4 \%$ & $3.3 \%$ & $00 \%$ \\
\hline May $16^{\text {th }}$ & $33.19 \%$ & $4.69 \%$ & $3.1 \%$ & $-0.2 \%$ \\
\hline
\end{tabular}

Above table shows the ratio of total cases confirmed to total cases recovered and the ratio of total cases confirmed to total death cases. These ratios has been derived by using following formulas:
1) $\quad$ Total recovered cases
Total confirmed cases
2) Total Death cases
Total confirmed cases 
This table shows that the ratio of recovered cases of corona to confirmed cases of corona in India from the date of $15^{\text {th }}$ March to $16^{\text {th }}$ May shows up and down trend. On the date of $15^{\text {th }}$ march it is $0 \%$, It increase to $13 \%$ on the date of March $14^{\text {th }}$. This ratio decrease to $6.3 \%$ on April $4^{\text {th }}$.From April $11^{\text {th }}$ to May $16^{\text {th }}$ this ratio shows increasing trend i.e.9.1 \% to $33.19 \%$ But the percentage change in this ratio vary from one week to another week. It decrease by $5.77 \%$ from the date $14^{\text {th }}$ march to $21^{\text {st }}$ march. Whereas it increase by $13 \%$ from $7^{\text {th }}$ march 2020 to $14^{\text {th }}$ April 2020.

Above table also shows the ratio of Death cases of corona to confirmed cases of corona In India from the date of $15^{\text {th }}$ March to $16^{\text {th }}$ May. In the beginning of this corona pandemic this ratio is $0 \%$ till $7^{\text {th }}$ march 2020 , then it started fluctuating between $2.7 \%$ to $3.4 \%$. On the dtae of $16^{\text {th }}$ may it is $3.1 \%$. As well as the percentage changes in the ratio also vary week to week. It is decreased to $0.5 \%$ from the date $14^{\text {th }}$ march to $21^{\text {st }}$ march and increase by $2 \%$ from from $7^{\text {th }}$ march 2020 to $14^{\text {th }}$ April 2020 . Above ratio shows that there is no positive,negative and constant relation between corona confirmed ,recovered and death cases as the ratio of recovered to conformed cases is increasing from the April $4^{\text {th }}$ to $16^{\text {th }}$ may 2020 but the ratio of corona death cases to confirmed cases is not decreasing in the same period. It vary week to week.

\section{Figure 3: Ratio Of Total confirmed Cases To Total Cases Recovered And The Ratio Of Total Cases Impacted To Total Death Cases In India}

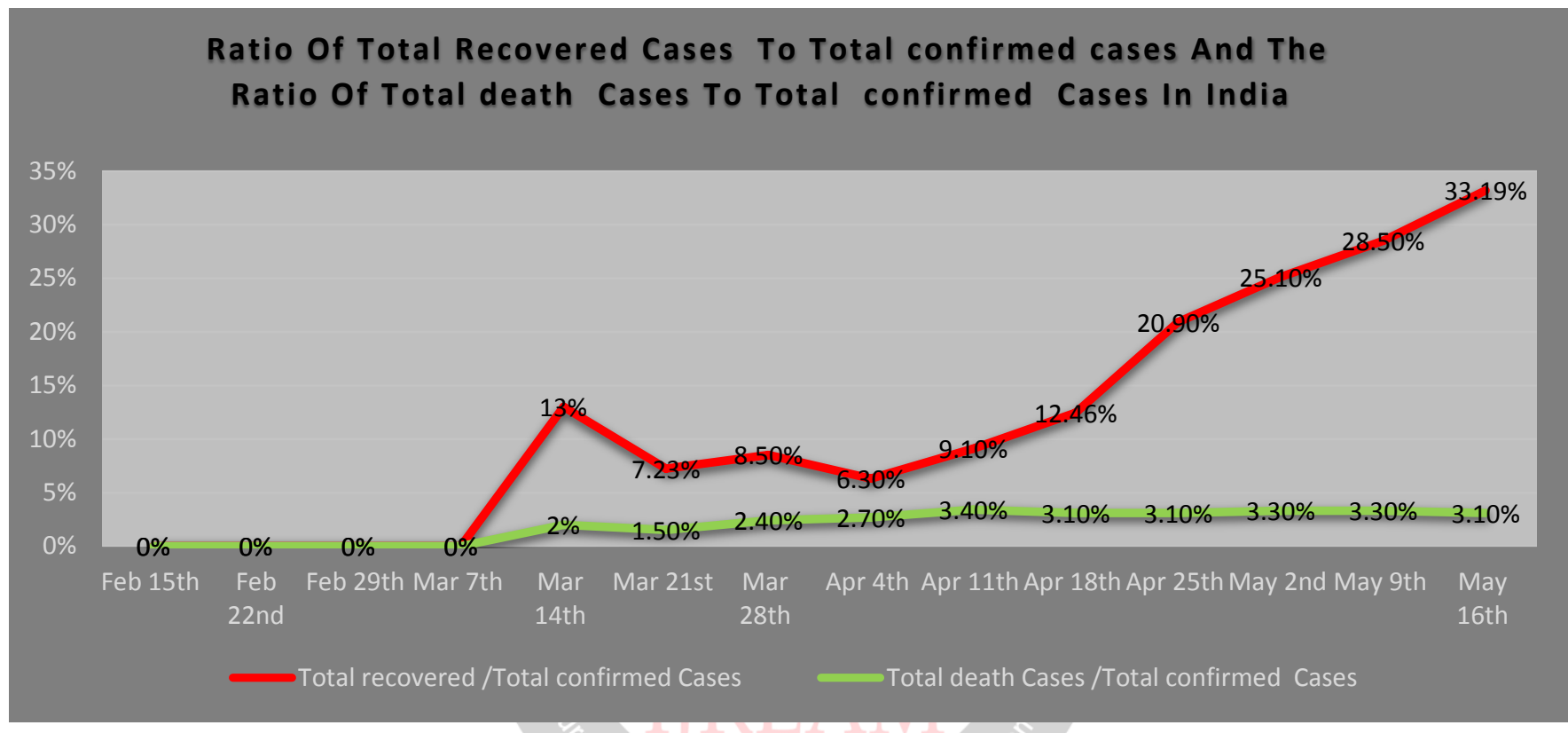

In the above graph red line shows the ratio of recovered to confirmed cases and green line shows the ratio of death cases to confirmed cases. From $15^{\text {th }}$ feb to 7 march for this 4 week these both ratios are $0 \%$. then recovered to confirmed cases ratio increase to $13 \%$ and death to confirmed ratio increase to $2 \%$ and these ratios are $33.19 \%$ and $3.10 \%$ respectively on $16^{\text {th }}$ May 2020. Above graph shows that these both ratios are neither continuously increasing nor decreasing. They are varying time to time and shows up and down trend in selected time period of two months.

\section{FINDINGS}

i. Table and Figure no 2 shows that confirmed recovered and death cases of corona in India are increasing from $15^{\text {th }}$ Feb to $16^{\text {th }}$ June 2020.

ii. Table and figure 3 shows that the ratio of recovered cases to confirmed cases is neither continuously increasing nor decreasing from $15^{\text {th }}$ Feb to $16^{\text {th }}$ June 2020.

iii. Table and figure 3 shows that the ratio of death cases to confirmed cases is neither continuously increasing nor decreasing from $15^{\text {th }}$ Feb to $16^{\text {th }}$ June 2020.

\section{ConcLuSION}

Study has been conducted to find out the relationship between confirmed, recovered and death cases in India. For this study the data from the $15^{\text {th }}$ feb 2020 to $16^{\text {th }}$ April 2020 has been collected. With the help of ratio analysis we conclude that,

The ratio of corona recovered cases to confirmed cases increase from the $4^{\text {th }}$ march 2020 .

The ratio of corona death cases to confirmed cases shows ups and down trends from the $4^{\text {th }}$ march 2020 . Increase in the confirm cases leads to increase in the recovered and death cases of corona in India. The increase in the ratio of total recovered cases to total confirmed cases does not leads to decrease in the ratio of total death cases to total confirmed cases of corona. At some point there is increase 
in the recover cases as well as increase in the death cases. The reason behind it might be age ,medical history of the patient. The null hypothesis is accepted.

\section{REFERENCES}

[1] https://en.wikipedia.org/

[2] https://www.worldometers.info/

[3] https://covidindia.org/

[4] Management Accounting, Himalaya Publication

[5] https://www.deccanherald.com/

[6] https://tradingeconomics.com/

[7] https://www.worldometers.info/

[8] https://www.who.int/

[9] https://uidai.gov.in/

[10] https://www.thehindu.com/

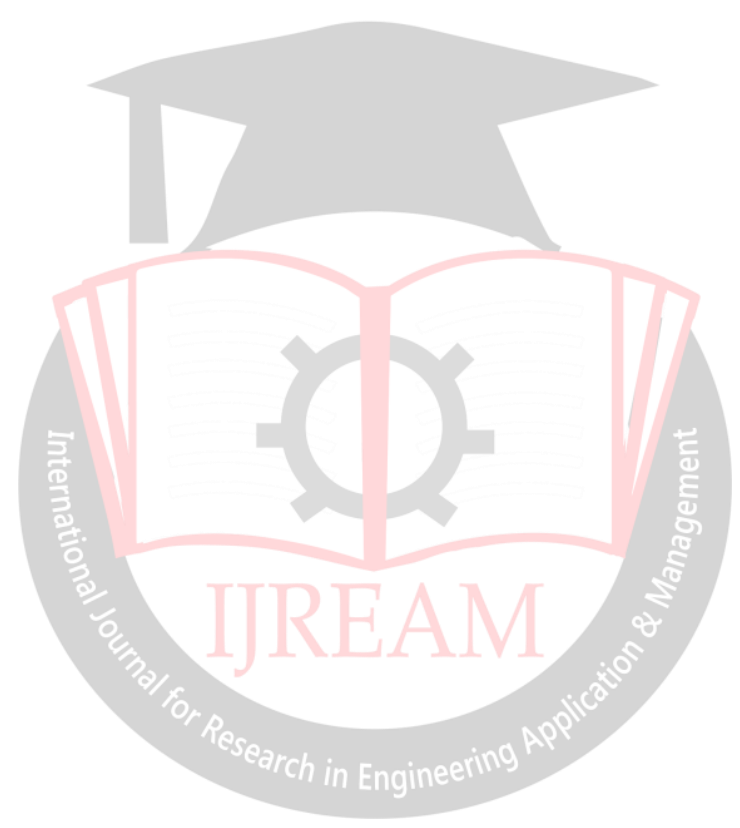

